\title{
Videos of Savi Oriented Learning Model Based on Sparcol Scribe in Class IV Students
}

\author{
Niya selfiana panggabean ${ }^{1 *}$, I Kadek Suartama ${ }^{2 *}$, I Made Tegeh ${ }^{3 *}$ (iD \\ 1,2,3 Teknologi Pendidikan, Universitas Pendidikan Ganesha, Singaraja, Indonesia \\ *Corresponding author: niyaselfianapanggabean@undiksha.ac.id ${ }^{1}$
}

\section{Abstrak}

Rendahnya hasil belajar siswa kelas IV Sekolah dasar pada pembelajaran IPS disebabkan oleh pengkemasan pembelajaran kurang menarik. Selain itu, belum adanya penerapan video pembelajaran interaktif di kelas. Tujuan penelitian mengembangkan video pembelajaran interaktif. Jenis penelitian ini yaitu pengembangan dengan model ADDIE. Metode pengumpulan data terdiri dari wawancara, observasi, pencatatan dokumen, serta menyebarkan kuesioner. Subjek penelitian ini terdiri 3 pakar ahli, 6 siswa kelompok kecil dan 3 siswa uji perorangan. Instrumen yang digunakan untuk mengumpulkan data yaitu kuesioner. Teknik yang digunakan untuk menganalisis data yaitu analisis dekriptif kualitatif dan kuantitatif. Hasil penelitian yaitu hasil review ahli isi bidang studi dengan kualifikasi sangat baik (96,66\%). Hasil review ahli desain media dengan kualifikasi sangat baik (96\%). Hasil review ahli media dengan kualifikasi sangat baik (90\%). Hasil uji coba perorangan dengan kualifikasi sangat baik (96,67\%). Hasil uji coba kelompok kecil dengan kualifikasi sangat baik (95,55\%). Dapat disimpulkan bahwa, penggunaan video pembelajaran interaktif layak diterapkan dalam pembelajaran. Video pembelajaran dapat meningkatkan minat belajar siswa terhadap Ilmu pengetahuan sosial.

Kata kunci: Video pembelajaran, interaktif, SAVI

\section{Abstract}

The low learning outcomes of fourth-grade elementary school students in social studies learning are caused by less attractive learning packaging. In addition, there is no application of interactive learning videos in the classroom. The research objective is to develop interactive learning videos. This type of research is the development of the ADDIE model. Data collection methods consist of interviews, observation, document recording, and distributing questionnaires. This study consisted of 3 experts, 6 small group students, and 3 individual test students. The instrument used to collect data is a questionnaire. The technique used to analyze the data is descriptive qualitative and quantitative analysis. The study results are the results of a review by content experts in the field of study with excellent qualifications (96.66\%). The results of the review of media design experts with excellent qualifications $(96 \%)$. The results of the review of media experts with excellent qualifications (90\%). The results of individual trials with excellent qualifications (96.67\%). The results of the small group trial with excellent qualifications $(95.55 \%)$. It can be concluded that the use of interactive learning videos is feasible to be applied in learning. Learning videos can increase students' interest in social science.

Keywords: Learning videos, interactive, SAVI

$\begin{array}{ll}\text { History: } & \\ \text { Received } & \text { : March 19, } 2021 \\ \text { Revised } & \text { : March 21, 2021 } \\ \text { Accepted } & \text { : June 10, 2021 } \\ \text { Published } & \text { : July 25, } 2021\end{array}$

\section{Introduction}

Education is the learning of knowledge, skills, and habits of a group of people passed down from one generation to the next through teaching, training, or research (Gonźalez et al., 2013; Syauqi et al., 2020). Any experience that has a formative effect on the way people think feel, or act can be considered educational (Bui \& Do Van Dung, 2019; Kratz et al., 2019). Education is generally divided into preschool, elementary school, junior high school, high school, college, university, or internship (Chai \& Kong, 2017; H. Tseng et al., 2019). Therefore, improving the quality of education is an essential concern in improving the quality of human resources ((Pane \& Rina Patriana, 2016; Singh, 2019). Education is a 
process by which a person acquires knowledge that can later help improve human resources.

In the learning process, selecting and using the correct method in presenting material can help students know and understand the material presented by the teacher (CabaleiroCerviño \& Vera, 2020; Gil-Flores et al., 2017). However, many teachers may still lack the use of Information Technology (IT) (Oktaviani et al., 2020; Tuma, 2021). So that in online learning and classroom learning, teachers are more dominant in providing learning to students only by using modules/e-modules and other material summaries that are only in the form of text (Asrial et al., 2020; Velan et al., 2015). The characteristics of independent learning in each student will appear if students have shown changes in learning (Hockings et al., 2018; Rabgay, 2018). Students learn to be responsible for the tasks assigned to them independently and not depend on others. It is necessary to apply media in the learning process (Dhika et al., 2019; Syahroni et al., 2016).

Based on the interviews and needs analysis results through interviews and questionnaires conducted with fourth-grade social science subject teachers at SDN 091617 Serbelawan. It was obtained information that the learning resources used by teachers in the learning process were still in the form of simple learning media, such as printed teaching materials and simple presentation media. It is due to the lack of knowledge of teachers who have to prepare teaching materials for each class that will be used in each lesson, causing students to tend to be bored in participating in learning plus the material contained in printed teaching materials is very dense and makes students less interested in learning. If educators are not innovative in facilitating the learning process, it will affect student learning outcomes. The average value of UTS and UAS results for fourth-grade students in social studies subjects for the 2020/2021 academic year is 70, but there are still seven out of 30 students who score below the KKM and students who only reach the KKM.

Based on this background, the solution that can be offered to attract students' attention in learning so as to improve student learning outcomes is to develop interactive learning videos. Learning media as a component of the learning system must be in accordance with the learning components so that optimal function in learning activities (Budiarto et al., 2020; Khamparia \& Pandey, 2017; Suryanda et al., 2019). The presence of learning media is certainly able to improve the quality of learning (Kartika et al., 2019; Tere et al., 2020). Learning media are everything that can be used to channel messages, so that it can stimulate interests, thoughts and feelings of students' learning (Darmaji et al., 2019; Lawrence \& Tar, 2018). In this case, many media can be used in the learning process, such as videos, presentation slides, or using media directly.

Interactive learning videos in the learning process effectively stimulate students' cognitive and language aspects (Hanif, 2020; Pamungkas et al., 2018). Interactive learning videos significantly affect student motivation and learning outcomes (Leatherman \& Cleveland, 2020; Van Alten et al., 2019). From the explanation of these objectives, social science subjects should be equipped starting from elementary school to hone their logical, analytical, systematic, critical, and creative thinking skills and the ability to work together (Bettencourt et al., 2011; TucksanunKlahan \& Yuenyong, 2012). Of the competencies mentioned, related to real-life, students can obtain, manage, and use the information to live in conditions that are often changing, uncertain, and competitive (Bakırc1 et al., 2011; Hwang et al., 2020).

In order to achieve the learning objectives of Social Sciences, it is necessary to have a social science learning process in practice as follows: active student-centered learning activities, providing freedom of thought in understanding problems, making problem-solving strategies, conveying ideas with free and open. Directing and training so that students can think critically and creatively in solving problems, design learning to work together in study groups, train to express opinions using graphs, diagrams, schemes, and variables, in learning 
(Dhiu, 2017; Weiss et al., 2018).

The findings of previous research stated that learning videos would help students learn (Rose et al., 2016; S. Tseng, 2021). Other research findings state that learning videos will make it easier for students to understand learning materials (Andel et al., 2020; Hanif, 2020; Li et al., 2021). Other research also states that learning media will increase students' enthusiasm for learning (Mortazavi, 2011; Sun \& Gao, 2016; (Mark) Feng Teng, 2019). Can the key that learning video media can facilitate students in learning. This research aims to develop a sparkol scribe interactive learning video for fourth-grade elementary school students. With this interactive learning video, it will be an alternative that teachers can use in developing and learning more creative and innovative so that it can improve student learning outcomes.

\section{Methods}

This type of research is development research. This research was conducted at SD Negeri 091617 Serbelawan grade IV. The subjects of this study were all fourth-grade students who collected 30 students. The development procedure used refers to the ADDIE model, which consists of analysis, design, development, implementation, and evaluation (Harjanta \& Herlambang, 2018). The subjects of this study were experts on learning content, instructional design, instructional media, and fourth-grade elementary school students. The subjects of the individual product trial were 3 fourth-grade students at SDN 091617 Serbelawan. The small group trial subjects opened 6 students. The methods used to collect data are observation, interviews, and questionnaires. The instrument used to collect data is a questionnaire. The techniques used to analyze the data are descriptive qualitative statistical analysis techniques and quantitative statistics. Qualitative descriptive analysis is used to process data in the form of sentences or words given by experts. Quantitative descriptive analysis is used to process data in the form of numbers.

\section{Results and Discussion Results}

Considering the assessment results of aspects of learning videos by material experts, media experts, and students, it can be said that the learning media developed are included in the sound and excellent categories. The research results on this development will discuss the process of developing interactive learning videos and the validity of interactive learning videos. The process of developing interactive learning videos in this study uses the ADDIE development model. Developing this interactive learning video passes through five stages. The first stage is the analysis stage. At this stage, four things are analyzed, namely 1) needs analysis, 2) student characteristics analysis, 3) competency analysis, 4) facilities and infrastructure analysis. This analysis stage was carried out through interviews and questionnaires via a google form. The second stage is the design stage. At this stage, namely 1) making a flowchart, 2) developing a storyboard, 3) selecting the software to be used, sparkol scribe and also filmora 4) compiling an assessment instrument.

The third stage is the development stage. This stage is the stage of developing a design made into an actual product that will later be tested for feasibility. The fourth stage is the implementation stage. At the implementation stage, the activities carried out are 1) product validity testing by experts including learning content experts, learning design experts, learning media experts, 2) product trials which include individual trials and small group trials. The purpose of conducting product validation tests and product trials is to determine the attractiveness, effectiveness of the product, and the feasibility of the product developed as a learning resource. The last stage is the evaluation stage. The evaluation stage is to revise again according to the input, suggestions and comments received after the 
feasibility test is carried out to students.

The validity of interactive learning videos is determined based on the results of reviews from learning content experts, learning design experts, learning media experts, individual trials, and small group trials. Based on the validity test results of interactive learning video products conducted by the content experts, the Craft learning content obtained a percentage of $96.6 \%$ with excellent qualifications. Learning media experts obtained a percentage of $96 \%$ with suitable qualifications. Learning design expert test obtained a percentage of $90 \%$ with suitable qualifications. The individual test trials obtained a percentage of $96.67 \%$ with excellent qualifications. The small group trials obtained a percentage of $95.55 \%$ with excellent qualifications. Through the validity results, interactive learning video products get suggestions, input, and comments, which will be used as a reference for revising the product for the perfection of interactive learning video products. The results of developing interactive learning videos are shown in the image below.

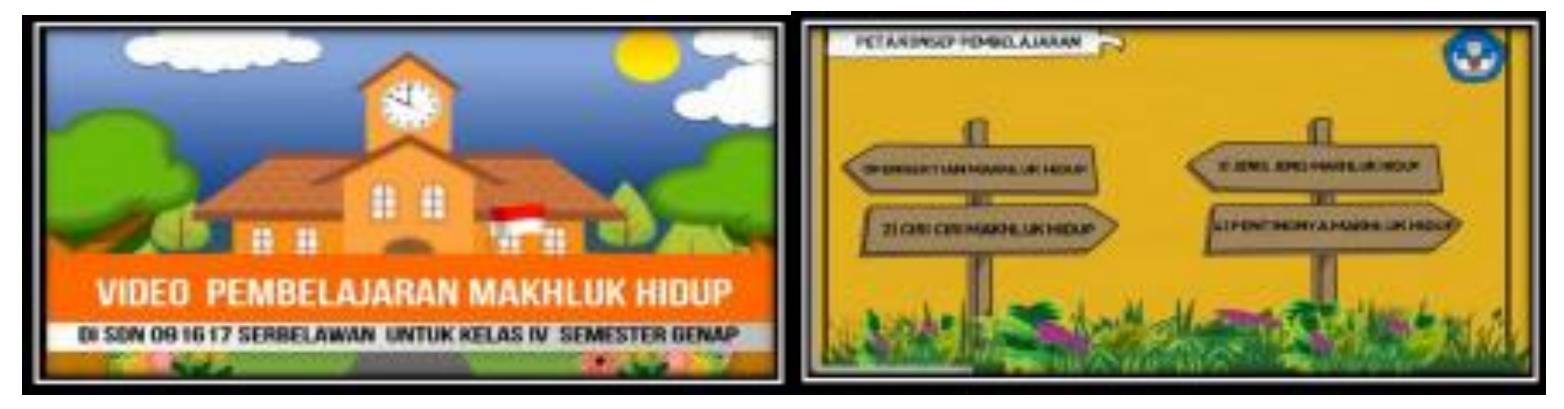

Figure 1. Learning Videos Developed

\section{Discussion}

Based on the research on the validity test results, interactive learning videos were developed to be used as learning resources. It is also because developing interactive learning videos uses a systematic development model to minimize errors in the development process (Alnajdi, 2018; Hamzah \& Mentari, 2017). Learning videos developed by utilizing technology. In overcoming the low quality of learning, one must also pay attention to the development of science and technology (Chin \& Wang, 2021; Yavuz et al., 2021). The use of technology in learning will help students learn (Bayles et al., 2021; Muhtadi et al., 2018).

In addition, the material presented in the media is by the essential competencies and the learning objectives used. It makes it easier for students to learn (Andel et al., 2020; Mutakinati et al., 2018). The material is also presented with obvious details and examples to help students understand the material. The material presented clearly and clearly will help students better understand the material described and provide better learning outcomes (Gjems, 2013; Van Alten et al., 2020).

In the design of interactive learning video products in social science learning, the material presentation design is appropriate. It causes students to be more motivated in learning (Bajrami \& Ismaili, 2016; Mpungose, 2021; Nurdin et al., 2019). Learning design is an effort to systematically develop learning components using specific theories so that they must be considered carefully (Colasante \& Douglas, 2016; Kamelia, 2019). Thus, a wellorganized learning design will help the student's learning process (Nonthamand, 2020; M. F. Teng, 2019). The learning process has systematic stages that will facilitate the learning process and increase student learning motivation.

Motivation is one of the most critical dynamic aspects (Hosen et al., 2021; Liu, 2020). Increasing students' learning motivation certainly requires positive things to attract students' attention to learning (Khan et al., 2019; Saito et al., 2018). One of them by using interactive 
media. With the correct method, teacher difficulties in delivering material can be minimized with the help of teaching aids and media in learning (Priantini, 2020; Rose et al., 2016). Based on the discussion results above, this interactive learning video can increase students' interest and motivation in learning and is implied as a learning resource that can be used in the learning process to improve student learning outcomes.

\section{Conclusion}

Interactive learning videos on the subject of Social Sciences achieve excellent qualifications from experts. It can be concluded that this interactive learning media deserves to be used as a learning resource in the online learning process and the offline classroom to attract students' interest in learning and increase student motivation in learning.

\section{References}

Alnajdi, S. M. (2018). The Effectiveness of Designing and Using a Practical Interactive Lesson based on ADDIE Model to Enhance Students' Learning Performances in University of Tabuk. Journal of Education and Learning, 7(6), 212. https://doi.org/10.5539/jel.v7n6p212

Andel, S. A., de Vreede, T., Spector, P. E., Padmanabhan, B., Singh, V. K., \& Vreede, G. J. de. (2020). Do social features help in video-centric online learning platforms? A social presence perspective. Computers in Human Behavior, 113(April), 106505. https://doi.org/10.1016/j.chb.2020.106505

Asrial, Syahrial, Maison, M., Kurniawan, D. A., \& Piyana, S. O. (2020). Ethnoconstructivism E-Module to Improve Perception, Interest, And Motivation of Students in Class V Elementary School. Jurnal Pendidikan Indonesia, 9(1), 30-41. https://doi.org/10.23887/jpi-undiksha.v9i1.19222

Bajrami, L., \& Ismaili, M. (2016). The Role of Video Materials in EFL Classrooms. Procedia Social and Behavioral Sciences, 232(April), 502-506. https://doi.org/10.1016/j.sbspro.2016.10.068

Bakırc1, H., Bilgin, A. K., \& Simsek, A. (2011). The effects of simulation technique and worksheets on formal operational stage in science and technology lessons. Procedia Social and Behavioral Sciences, 15. https://doi.org/10.1016/j.sbspro.2011.03.311

Bayles, J., Peterson, A. D., Pitts, S. J., Bian, H., Burkholder, S., Hegde, A. V., \& Stage, V. C. (2021). Food-Based Science, Technology, Engineering, Arts, and Mathematics (STEAM) Learning Activities May Reduce Decline in Preschoolers' Skin Carotenoid Status. Journal of Nutrition Education and Behavior, 53(4). https://doi.org/10.1016/j.jneb.2020.10.017

Bettencourt, C., Velho, J. L., \& Almeida, P. A. (2011). Biology teachers' perceptions about Science-Technology-Society (STS) education. Procedia - Social and Behavioral Sciences, 15. https://doi.org/10.1016/j.sbspro.2011.04.262

Budiarto, M. K., Joebagio, H., \& Sudiyanto, S. (2020). Student's View of Using Digital Learning Media in Classroom Activities: A Case of Public Senior High School in Cirebon, Indonesia. Jurnal Pendidikan Progresif, 10(1). https://doi.org/10.23960/jpp.v10.i1.202006

Bui, V. H., \& Do Van Dung. (2019). Development of Vietnamese Vocational Education Teachers to adapt the Industrial Revolution 4.0. Asian Journal of Interdisciplinary Research, 2(4), 1-7. https://doi.org/10.34256/ajir1941

Cabaleiro-Cerviño, G., \& Vera, C. (2020). The Impact of Educational Technologies in Higher Education. GIST - Education and Learning Research Journal, 20, 155-169. https://doi.org/10.26817/16925777.711 
Chai, C. S., \& Kong, S.-C. (2017). Professional learning for 21st century education. Journal of Computers in Education, 4(1), 1-4. https://doi.org/10.1007/s40692-016-0069-y

Chin, K.-Y., \& Wang, C.-S. (2021). Effects of augmented reality technology in a mobile touring system on university students' learning performance and interest. Australasian Journal of Educational Technology, 37(1). https://doi.org/10.14742/ajet.5841

Colasante, M., \& Douglas, K. (2016). Prepare-participate-connect: Active learning with video annotation. Australasian Journal of Educational Technology, 32(4), 68-91. https://doi.org/10.14742/ajet.2123

Darmaji, Kurniawan, D. A., Astalini, Lumbantoruan, A., \& Samosir, S. C. (2019). Mobile learning in higher education for the industrial revolution 4.0: Perception and response of physics practicum. In International Journal of Interactive Mobile Technologies (Vol. 13, Issue 9). https://doi.org/10.3991/ijim.v13i09.10948

Dhika, H., Destiawati, F., Sonny, M., \& Surajiyo. (2019). Study of the use and application of the moodle e-learning platform in high school. Journal of Physics: Conference Series, 1175, 012219. https://doi.org/10.1088/1742-6596/1175/1/012219

Dhiu, K. D. (2017). Learning Motivation And Perception Of The Teachers' Pedagogic Competence And Learning Achievement In Social Science Of Junior High School Students. Journal of Education Technology, 1(1), 6-12. https://doi.org/10.23887/jet.v1i1.10078

Gil-Flores, J., Rodríguez-Santero, J., \& Torres-Gordillo, J. J. (2017). Factors that explain the use of ICT in secondary-education classrooms: The role of teacher characteristics and school infrastructure. Computers in Human Behavior, 68, 441-449. https://doi.org/10.1016/j.chb.2016.11.057

Gjems, L. (2013). Teaching in ECE: Promoting children's language learning and cooperation on knowledge construction in everyday conversations in kindergarten. Teaching and Teacher Education, 29(1), 39-45. https://doi.org/10.1016/j.tate.2012.08.008

Gonźalez, Guzḿan, Dormido, \& Berenguel. (2013). Development of Interactive Books for Control Education. IFAC Proceedings Volumes (IFAC-PapersOnline), 46(17). https://doi.org/10.3182/20130828-3-UK-2039.00043

Hamzah, I., \& Mentari, S. (2017). Development of Accounting E-Module to Support the Scientific Approach of Students Grade X Vocational High School. Journal of Accounting and Business Education, 1(1), 78. https://doi.org/10.26675/jabe.v1i1.9751

Hanif, M. (2020). The development and effectiveness of motion graphic animation videos to improve primary school students' sciences learning outcomes. International Journal of Instruction, 13(4), 247-266. https://doi.org/10.29333/iji.2020.13416a

Harjanta, A. T. J., \& Herlambang, B. A. (2018). Rancang Bangun Game Edukasi Pemilihan Gubernur Jateng Berbasis Android Dengan Model ADDIE. Jurnal Transformatika, 16(1), 91-97. https://doi.org/10.26623/transformatika.v16i1.894

Hockings, C., Thomas, L., Ottaway, J., \& Jones, R. (2018). Independent learning-what we do when you're not there. Teaching in Higher Education, 23(2), 145-161. https://doi.org/10.1080/13562517.2017.1332031

Hosen, M., Ogbeibu, S., Giridharan, B., Cham, T.-H., Lim, W. M., \& Paul, J. (2021). Individual motivation and social media influence on student knowledge sharing and learning performance: Evidence from an emerging economy. Computers \& Education, 72. https://doi.org/10.1016/j.compedu.2021.104262

Hwang, G. J., Wang, S. Y., \& Lai, C. L. (2020). Effects of a social regulation-based online learning framework on students' learning achievements and behaviors in mathematics. $\begin{array}{llll}\text { Computers aducation, } & \text { and } & 104031 .\end{array}$ https://doi.org/10.1016/j.compedu.2020.104031

Kamelia, K. (2019). Using Video as Media of Teaching in English Language Classroom: 
Expressing Congratulation and Hopes. Utamax: Journal of Ultimate Research and Trends in Education, 1(1), 34-38. https://doi.org/10.31849/utamax.v1i1.2742

Kartika, Y., Wahyuni, R., Sinaga, B., \& Rajagukguk, J. (2019). Improving Math Creative Thinking Ability by using Math Adventure Educational Game as an Interactive Media. Journal of Physics: Conference Series, 1179(1), 1-6. https://doi.org/10.1088/17426596/1179/1/012078

Khamparia, A., \& Pandey, B. (2017). Impact of interactive multimedia in E-learning technologies: Role of multimedia in E-learning. Enhancing Academic Research With Knowledge Management Principles, April, 199-227. https://doi.org/10.4018/978-15225-2489-2.ch007

Khan, T., Johnston, K., \& Ophoff, J. (2019). The Impact of an Augmented Reality Application on Learning Motivation of Students. Advances in Human-Computer Interaction. https://doi.org/10.1155/2019/7208494

Kratz, F., Patzina, A., Kleinert, C., \& Dietrich, H. (2019). Vocational education and employment: Explaining cohort variations in life course patterns. Social Inclusion, 7(3), 224-253. https://doi.org/10.17645/si.v7i3.2045

Lawrence, J. E., \& Tar, U. A. (2018). Factors that influence teachers' adoption and integration of ICT in teaching/learning process. Educational Media International, 55(1), 79-105. https://doi.org/10.1080/09523987.2018.1439712

Leatherman, J. L., \& Cleveland, L. M. (2020). Student exam performance in flipped classroom sections is similar to that in active learning sections, and satisfaction with the flipped classroom hinges on attitudes toward learning from videos. Journal of Biological Education, 54(3), 328-344. https://doi.org/10.1080/00219266.2019.1575266

Li, C., Zhang, J., \& Yao, J. (2021). Streamer action recognition in live video with spatialtemporal attention and deep dictionary learning. Neurocomputing, 453. https://doi.org/10.1016/j.neucom.2020.07.148

Liu, I.-F. (2020). The impact of extrinsic motivation, intrinsic motivation, and social selfefficacy on English competition participation intentions of pre-college learners: Differences between high school and vocational students in Taiwan. Learning and Motivation, 72. https://doi.org/10.1016/j.1mot.2020.101675

Mortazavi, S.-M. (2011). The relationship between time lapse between introducing lexical advance organizers and video viewing, and comprehension in a foreign language classroom. Procedia - Social and Behavioral Sciences, 15. https://doi.org/10.1016/j.sbspro.2011.04.047

Mpungose, C. B. (2021). Lecturers' reflections on use of Zoom video conferencing technology for e-learning at a South African university in the context of coronavirus. African Identities. https://doi.org/10.1080/14725843.2021.1902268

Muhtadi, D., Wahyudin, Kartasasmita, B. G., \& Prahmana, R. C. I. (2018). The Integration of technology in teaching mathematics. Journal of Physics: Conference Series, 943(1), 19. https://doi.org/10.1088/1742-6596/943/1/012020

Mutakinati, L., Anwari, I., \& Yoshisuke, K. (2018). Analysis of students' critical thinking skill of middle school through stem education project-based learning. Jurnal Pendidikan IPA Indonesia, 7(1), 54-65. https://doi.org/10.15294/jpii.v7i1.10495

Nonthamand, N. (2020). Guideline to develop an instructional design model using video conference in open learning. International Journal of Emerging Technologies in Learning, 15(3), 140-155. https://doi.org/10.3991/ijet.v15i03.10842

Nurdin, E., Ma'aruf, A., Amir, Z., Risnawati, R., Noviarni, N., \& Azmi, M. P. (2019). Pemanfaatan video pembelajaran berbasis Geogebra untuk meningkatkan kemampuan pemahaman konsep matematis siswa SMK. Jurnal Riset Pendidikan Matematika, 6(1), 87-98. https://doi.org/10.21831/jrpm.v6i1.18421 
Oktaviani, A., Anom, K., \& Lesmini, B. (2020). Pengembangan Modul Kimia terintegrasi STEM (Science, Technology, Engineering and Mathematics) dan PBL (Problem-Based Learning). Journal of Educational Chemistry (JEC), 2(2), 64. https://doi.org/10.21580/jec.2020.2.2.6279

Pamungkas, A. S., Ihsanudin, I., Novaliyosi, N., \& Yandari, I. A. V. (2018). Video Pembelajaran Berbasis Sparkol Videoscribe: Inovasi Pada Perkuliahan Sejarah Matematika. Prima: Jurnal Pendidikan Matematika, 2(2), 127. https://doi.org/10.31000/prima.v2i2.705

Pane, M. M., \& Rina Patriana. (2016). The Significance of Environmental Contents in Character Education for Quality of Life. Procedia - Social and Behavioral Sciences, 222, 244-252. https://doi.org/10.1016/j.sbspro.2016.05.153

Priantini, D. A. (2020). The Development Of Teaching Video Media Based On Tri Kaya Parisudha In Educational Psychology Courses. Journal of Education Technology, 4(4). https://doi.org/10.23887/jet.v4i4.29608

Rabgay, T. (2018). The effect of using cooperative learning method on tenth grade students' learning achievement and attitude towards biology. International Journal of Instruction, 11(2), 265-280. https://doi.org/10.12973/iji.2018.11218a

Rose, J. A., O’Meara, J. M., Gerhardt, T. C., \& Williams, M. (2016). Gamification: using elements of video games to improve engagement in an undergraduate physics class. Physics Education, 51(5). https://doi.org/10.1088/0031-9120/51/5/055007

Saito, K., Dewaele, J.-M., Abe, M., \& In'nami, Y. (2018). Motivation, Emotion, Learning Experience, and Second Language Comprehensibility Development in Classroom Settings: A Cross-Sectional and Longitudinal Study. Language Learning, 68(3), 709743. https://doi.org/10.1111/lang.12297

Singh, B. (2019). Character education in the 21st century. Journal of Social Studies (JSS), 15(1), 1-12. https://doi.org/10.21831/jss.v15i1.25226

Sun, H., \& Gao, Y. (2016). Impact of an active educational video game on children's motivation, science knowledge, and physical activity. Journal of Sport and Health Science 5, 1(1), 239-245. https://doi.org/10.1016/j.jshs.2014.12.004

Suryanda, A., Sartono, N., \& Sa'diyah, H. (2019). Developing smartphone-based laboratory manual as a learning media. Journal of Physics: Conference Series, 402. https://doi.org/10.1088/1742-6596/1402/7/077077

Syahroni, M. W., Dewi, N. R., \& Kasmui. (2016). The Effect of Using Digimon (Science Digital Module) with Scientific Approach at the Visualization of Students' Independence and Learning Results. Jurnal Pendidikan IPA Indonesia, 5(1), 116-122. https://doi.org/10.15294/jpii.v5i1.5800

Syauqi, K., Munadi, S., \& Triyono, M. B. (2020). Students' perceptions toward vocational education on online learning during the COVID-19 pandemic. International Journal of Evaluation and Research in Education (IJERE), 9(4), 881. https://doi.org/10.11591/ijere.v9i4.20766

Teng, (Mark) Feng. (2019). The effects of video caption types and advance organizers on incidental L2 collocation learning. Computers \& Education, 142. https://doi.org/10.1016/j.compedu.2019.103655

Teng, M. F. (2019). The effects of video caption types and advance organizers on incidental L2 collocation learning. Computers \& Education, 142. https://doi.org/10.1016/j.compedu.2019.103655

Tere, T., Bayu Seta, H., Nizar Hidayanto, A., \& Abidin, Z. (2020). Variables Affecting ELearning Services Quality in Indonesian Higher Education: Students' Perspectives. Journal of Information Technology Education: Research, 19, 259-286. https://doi.org/10.28945/4489 
Tseng, H., Yi, X., \& Yeh, H. T. (2019). Learning-related soft skills among online business students in higher education: Grade level and managerial role differences in selfregulation, motivation, and social skill. Computers in Human Behavior, 95. https://doi.org/10.1016/j.chb.2018.11.035

Tseng, S. (2021). The influence of teacher annotations on student learning engagement and video watching behaviors. International Journal of Educational Technology in Higher Education, 18(1), 1-17. https://doi.org/10.1186/s41239-021-00242-5

TucksanunKlahan, \& Yuenyong, C. (2012). An Analysis of Grade 12 Students' Technological Capability in Learning About Electromagnetics Through Science Technology and Society Approach (STS Approach). Procedia - Social and Behavioral Sciences, 46. https://doi.org/10.1016/j.sbspro.2012.06.390

Tuma, F. (2021). The use of educational technology for interactive teaching in lectures. Annals of Medicine and Surgery 62, 231-235. https://doi.org/10.1016/j.amsu.2021.01.051

Van Alten, D. C. D., Phielix, C., Janssen, J., \& Kester, L. (2019). Effects of flipping the classroom on learning outcomes and satisfaction: A meta-analysis. Educational Research Review, 28(June), 1-18. https://doi.org/10.1016/j.edurev.2019.05.003

Van Alten, D. C. D., Phielix, C., Janssen, J., \& Kester, L. (2020). Self-regulated learning support in flipped learning videos enhances learning outcomes. Computers and Education, 158(August), 104000. https://doi.org/10.1016/j.compedu.2020.104000

Velan, G. M., Goergen, S. K., Grimm, J., \& Shulruf, B. (2015). Impact of Interactive eLearning Modules on Appropriateness of Imaging Referrals: A Multicenter, Randomized, Crossover Study. Journal of the American College of Radiology, 12(11). https://doi.org/10.1016/j.jacr.2015.06.026

Weiss, D., Rydland, H. T., Øversveen, E., Jensen, M. R., Solhaug, S., \& Krokstad, S. (2018). Innovative technologies and social inequalities in health: A scoping review of the literature. PLoS ONE, 13(4), 1-20. https://doi.org/10.1371/journal.pone.0195447

Yavuz, M., Çorbacioğlu, E., Başoğlu, A. N., Daim, T. U., \& Shaygan, A. (2021). Augmented reality technology adoption: Case of a mobile application in Turkey. Technology in Society, 66. https://doi.org/10.1016/j.techsoc.2021.101598 